\title{
Ympäristöalan koulutuksen tulevaisuustarpeet
}

Johanna Kohl

VTL, johtava konsultti

Ramboll Finland Oy

PL3,Piispanmäentie5

02241 Espoo

johanna.kohl@ramboll.fi

\section{Tiivistelmä}

Kestävän kehityksen torille 2020-hanke on ollut OPM:n ESR-rahoitteinen projekti ajalla 2005-2007, jossa on selvitetty kestävän kehityksen mukaisen ympäristöalan korkeakoulutuksen määrällisiä ja laadullisia tarpeita vuoteen 2020.

Hankkeessa on pohdittu erityisesti generalististen koulutuksen, työelämän ja kansainvälisyyden haasteita. Hankkeen esiselvityksessä kartoitettiin ympärisöalan koulutuksen nykytilaa, jonka jälkeen paneuduttiin asiantuntijakyselyn ja haastatteluiden avulla (n=23) ympärisöalan koulutuksen tulevaisuusnäkymiin. Näistä syntyi skenaarioraportti. Tässä on hyödynnetty pääasiassa kvalitatiivisten haastatteluiden tuloksia. YK:n kestävän kehityksen vuosikymmenen (2005-2015) merkitystä käytännön koulutuksen kannalta pohdittiin visioimalla tulevaisuuden näkymiä mm. tohtorikoulutuksen ja yritysten tarpeiden kautta. Lisäksi pohdittiin koulutuksen ja työelämän joustavuuden ja muutoksen tarvetta mm. esittelemällä erilaisia urapolkuja sekä tulevaisuusverstaiden konkreettisia visioita. Yksinkertaistaen voi sanoa, että läpäisevä, mutta vastuullinen kestävän kehityksen koulutus on tulevaisuutta. Generalisteja, joilla on jonkinlainen käytännön valttikortti, tarvitaan yhä enemmän. Kansainvälisyys on niin mahdollisuus kuin haastekin, jossa eri alojen yhteistyötä pitäisi tiivistää - myös yliopistojen ja yritysten välillä. Vuoropuhelua tarvitaan lisää: uudenlaisille kohtaamispaikoille (keketorille) on tilaus jatkossakin.

Asiasanat: kestävä kehitys, koulutus, tulevaisuuden tutkimus 


\section{Johdanto}

Tulevaisuus rakentuu ja sitä rakennetaan koko ajan. Aika on jatkuvasti läsnä. Osuvasti tätä kuvaa intiaanien käsitys ajasta ja maanomistuksesta: "Maa kuuluu suurelle perheelle, joista monet ovat kuolleet, muutamat elossa ja lukematon määrä maan isännistä ovat vielä syntymättömiä”. Aikaulottuvuuden lisäksi ilman, lämmön, maan myyminen tai ostaminen hyödykkeenä tai niiden omistaminen tuntui intiaaneista käsittämättömältä: me olemme osa maata ja maa on osa meitä. (Coleman, 1994, 83.) Oikeastaan tuossa aikakäsityksessä on jotakin hyvin samanhenkistä kuin Brundtlandin raportissa Our Common Future (1987): Kestävä kehitys on kehitystä, joka tyydyttää nykyhetken tarpeet viemättä tulevilta polvilta mahdollisuutta tyydyttää omat tarpeensa.

Tässä artikkelissa on käytetty projektin ”Kestävän kehityksen torille 2020 -ympäristöalan määrälliset ja laadulliset koulutustarpeet 2020" -projektin keskeisiä tuloksia (ks. Kohl ja kumpp., 2007, Tapio ja kumpp., 2007 ja Kuosa ja kumpp., 2006).

Kestävää kehitystä lähestytään tässä seuraavien periaatteiden kautta:

1. ekologisten, teknistaloudellisten, sosio-kulttuuristen systeemien kriittisiä rajoja (sietokykyä)

ei ylitetä

2. ekologiset, teknis-taloudelliset, sosio-kulttuuriset tarpeet, tavoitteet ja käytännöt sovitetaan harmonisesti yhteen. (mukaillen Heinonen ym, 2003)

Tutkimuksessa mitään ulottuvuutta ei pidetty kattokäsitteenä, vaan niiden ajateltiin olevan lähtökohtaisesti tasavertaisia - olkoonkin, että sosio-kulttuurisen kestävän kehityksen olemuksesta tarvitaan enemmän keskustelua ja pohdiskelua (ks. Antola-Crowe ja Kohl, 2007).

Kestävä kehitys on tulevaisuuslähtöistä, ennakoivaa - ja innovatiivistakin ajattelua ja niin tulisi olla sen koulutuksenkin. Koulutuksen pitäisi pyrkiä vastaamaan kestävän kehityksen haasteisiin uusia ratkaisuja etsien ja niiden käyttöönottoa edistäen - ei jarruttaen. Kestävän kehityksen opettaminen antaa mahdollisuuksia kokeiluihin, joista voi koitua valttikortteja uusien ammattilaisten käyttöön. Tällainen on esimerkiksi nk. Pehmo-Gis-osaaminen (Kyttä \&Kahila, 2007), joka mahdollistaa esimerkiksi lasten kokemuksellisten ja näkemyksellisten asioiden yhdistämisen viheraluesuunnitteluun. Näin paikkatietojärjestelmii kehittämällä voidaan yhdistää sosiaaliset ja ekologiset kestävän kehityksen periaatteet konkreettisesti. Minkälaisia osaajia tulevaisuudessa siis tarvitaan: mitä odotuksia on työelämällä, yrityksillä? Onko genenalistit avainasemassa? Mitä haasteita tuo kansainvälistyminen?

Kestävä kehitys on horisontaalisesti ja vertikaalisesti käsiteltävä asia, jossa mm. sektoroituroitunut hallinto on uudistuspaineen alla. Vertikaalisen ajattelun ohella on otettava huomioon yli sektorirajojen menevä ajattelu ja toiminta, jotta kestävän kehityksen eri ulottuvuudet tulevat samanaikaisesti tunnistettua ja ymmärrettyä myös tulevaisuuden tarpeet ja tavoitteet huomioiden.

Pelkkä kestävä kehitys ei kuitenkaan kanna, vaan tarvitaan ylipäänsä yleissivistystä. Yhä enemmän työelämässä vaaditaan sosiaalisia taitoja alasta ja koulutusasteesta riippumatta. Pelkkä tietoasiantuntijuus ei riitä, jollei ole taitoasiantuntijuuskin kohdallaan.

\section{Aineistot ja menetelmät}

Mitä ovat generalistisen yleiskoulutuksen ja spesialistisen koulutuksen vahvuudet ja heikkoudet? Millä edellytyksillä ja miten laajasti generalistista ympäristöopetusta ja -tutkimusta voi järjestää?

Pitäisikö kestävän kehityksen koulutus ja ympäristökoulutus järjestää yhden ainelaitoksen kautta vai hajauttaa se eri oppiaineisiin. Onko esimerkiksi parempi, että ympäristöpsykologian opiskelijat saavat oppinsa psykologian laitokselta vai erikseen ympäristötieteilijöille räätälöidyltä kurssilta ympäristötieteen laitokselta?

Mitkä muut tekijät kuin substanssin osaaminen vaikuttavat ympäristöasiantuntijan työllistymiseen? Miten ne tulisi huomioida koulutussuunnittelussa? Mikä on koulutustason merkitys työllistymisessä? Entä ympäristöasiantuntijan työssä? Miten kansainvälistyminen on sekä haaste että mahdollisuus?

Näitä kysymyksiä syvennettiin esiselvityksen jälkeen teemahaastatteluilla ja Delfoi-kyselyllä, johon osallistui 23 ympäristökysymyksiä eri näkökulmista tarkastelevaa asiantuntijaa: viranomaisia, tutkijoita, opettajia, opiskelijoita sekä yritysten edustajia (vrt. KekeTori-tulevaisuusverstas). Asiantuntijapaneelin tarkemmat valintaperusteet löytyvät skenaarioraportista (Tapio ym. 2007). Tässä artikkelissa hyödynnetään pääasiassa kvalitatiivisten haastatteluiden tuloksia. 


\section{Tulokset: millaisia osaajia tulevaisuudessa tarvitaan?}

Kestävään kehitykseen liittyvät ongelmat ovat monimutkaisia ja monitulkintaisia. Niitä on vaikea lähestyä pelkän sektorikohtaisen spesiaalitiedon kautta. Yhteiskunnan toiminta on vahvasti sektoroitunutta ja sama ongelma heijastuu myös kestävää kehitystä edistävään koulutukseen. (Willamo, 1992.)

Kestävää kehitystä edistävässä koulutuksessa tulisi opiskelijoille antaa perustietoja monilta erilaisilta aloilta. Olennaista olisi saada mukaan kestävän kehityksen kaikki ulottuvuudet ja näiden kautta päästä ongelma- ja ilmiökeskeiseen yhteiskunnallisten ja ympäristöongelmien syiden ja seurausten pohdintaan. Koulutuksessa tulisi luopua ajatuksesta, että yksinomaan tieteellisesti toteennäytetty fakta on pätevää. Tieto on kontekstisidonnaista ja näin ollen erilaisten näkemysten, kokemusten ja arvojen merkitys tietojen ja tieteiden taustalla on tunnustettava.

Osaamisen ennakointi ja eri alojen välisen synergian ymmärtäminen, jossa panostetaan syvälliseen asioiden ja ilmiöiden ymmärtämiseen sekä strategiseen ajatteluun ovat $\mathrm{mm}$. Aaltosen ja Wileniuksen (2002) mukaan keskeisiä tulevaisuuden osaamistarpeita. Heikkojen signaalien tunnistajalle on heidän mukaansa kysyntää tulevaisuudessa. Osaajille, jotka tunnistavat erilaisia vahvoja virtauksia esimerkiksi koulutusalalla ja lähtevät pohtimaan ja ennakoimaan näiden virtausten mahdollista ja todennäköistä toteutumista. Siis konkreettisesti: ilmastonmuutos on tullut elämänkatsomustiedon opetustunnille. Tämä voisi olla yksi tunnistettu heikko signaali. Tosin signaali mistä?

Tulevaisuudessa tarvitaan innovatiivisia ammattilaisia monialaisten prosessien eteenpäin viemiseksi. Tämä edellyttää kumppanuutta erilaisten oppilaitosten, yhteisöjen, yritysten ja hallinnon välillä. Mitä on sosiaalisesti kestävä kaavoittajan toimissa ja mitä taas on esimerkiksi ekologisesti kestävää toimintaa sairaanhoitajan toimissa? Jotta nämä asiat voidaan ymmärtää, tarvitaan eri toimijoiden selkeä näkemys siitä, mitä kestävällä kehityksellä tavoitellaan, miten se ilmenee toimintoina ja miten kestävää kehitystä edistävät strategiat voidaan implementoida käytännössä. Eikä tämä riitä, vaan kestävä kehitys pitäisi tulla sisäistettyä niin, ettei sitä pidetä muista toiminnoista eroavana toimintana.

Näiden ajatusten siivittämänä tässä artikkelissa tarkastellaan kolmea kestävän kehityksen tulevaisuuden osaamistarpeeseen liittyvää keskeistä teemaa (Kohl ja kumpp., 2007)

1) generalistit ovat tulkkeja

2) spesialistejakin tarvitaan

3) uutta luovat keke-osaajat

\section{Generalistit ovat tulkkeja}

Sellaiselle asiantuntijoille, joiden koulutuksen lähtökohtana on ollut kestävä kehitys kaiken oppimisen perustana, eikä toisin päin, tulee olemaan tulevaisuudessa tarvetta. Tällainen koulutus tuottaa generalisteja, joilla on kuitenkin vankka perustieto ja osaaminen esimerkiksi ympäristönsuojelusta. Tutkimuksemme tuloksia analysoitaessa korostui kansainvälisyyden ja kansainvälisten tehtävien lisääntyminen tulevaisuudessa. Kansainvälistymishaasteeseen tulisi vastata myös koulutuksessa. Esimerkiksi vahvan kielitaidon lisäksi koulutuksessa tulisi vahvistaa kulttuurista kestävyyttä ja eri kulttuurien toimintakäytäntöjen tuntemusta ja herkkyyttä niiden huomioimiselle.

Generalistien tarve nousi esille myös siitä näkökulmasta, että tulevaisuuden työelämän tarpeita ja tehtäviä on vaikea ennakoida ja, että edessä voi olla suuriakin muutoksia. Tämä edellyttäisi koulutukselta muunneltavuutta ja joustavuutta vastata näihin tulevaisuuden työelämän muuttuviin tarpeisiin. Generalistien vahvuutena on muuntautumiskyky ja joustavuus työelämään rekrytoinnin näkökulmasta.

"Generalistin koulutus on käyttökelpoista, sillä työelämä ja sen myötä työtehtävät muuttuvat yhä kiihtyvällä vauhdilla, jolloin uudelleen suuntautuminen ja kouluttautuminen tapahtuu parhaiten generalistiselta pohjalta."

Generalistien osaamisen perusta on erilaisten tietojen ja taitojen yhdistäminen kestävän kehityksen periaatteiden mukaisesti. Toisin sanoen generalisti osaa käyttää esimerkiksi laadullisia ja määrällisiä menetelmiä toisiaan täydentävinä ja soveltaa tietojaan erilaisissa konteksteissa: generalisti voi olla tulkki, kun kartoitetaan hallinnon, yritysten ja poliittisten päättäjien keskustelua esimerkiksi kestävän kehityksen mukaisesta yhdyskuntasuunnittelusta. Koulutuksella tavoitellaan taitoa liittää, jäsentää ja arvioida pirstaleista tietoa ja erilaisia asioita kokonaisuudeksi kestävän kehityksen näkökulmasta.

Esimerkiksi ympäristöalan yleisosaajalle sosiaalinen vuorovaikutusverkosto on erityisen tärkeä poikkihallinnollisen yhteistyön toimivuuden kannalta ja tärkeä edellytys työtehtävien hoitamiselle. Yleisosaajan roolina on ymmärtää, tulkita ja kääntää yhteiselle kielelle muiden toimijoiden erityisalojen viestejä ja informaatiota, sekä työskennellä erityisalojen toimijoiden kanssa. 
”Ympäristöasiantuntijan pitää osata 'vaihtaa vaatteita' ja pystyä keskustelemaan esimerkiksi jätehuollosta niin it-yrityksessä, sairaalassa tai koulussa kuin hautausmaalla ja autokorjaamossakin. On osattava vaihtaa vaatteita konkreettisestikin, ja hypätä vaikkapa sairaalatakkiin ja keskustella sairaalan jäteongelmista kielellä, jota vastapuoli ymmärtää.”

Yleisosaajan koulutuksessa erittäin tärkeäksi nousevat sisällöllisten kysymysten lisäksi kommunikointi- ja vuorovaikutustaitojen oppiminen. Työllistymisen ja osaamisen kannalta myös verkottuminen ja sen merkityksen ymmärtäminen ovat avainasemassa. Opintoihin tuleekin sisällyttää runsaasti käytännön työharjoittelua ja yhteistyöprojekteja yritysten ja julkisen sektorin kanssa. Näin varmistetaan, että opiskelijoille syntyy jo opiskeluaikana teoreettisen tiedon lisäksi laaja näkemys kestävän kehityksen periaatteiden soveltamisesta käytäntöön.

Koulutuksessa kestävän kehityksen ulottuvuuksia käsitellään eri oppiaineiden kautta, ja ne nivoutuvat toinen toisiinsa: luonnonvara- ja ympäristöalan sekä sosiaali- ja terveysalan opiskelijat saatetaan toistensa pariin opiskelemaan kestävästä kehityksestä ja sen eri ulottuvuuksista. Kokonaisuutena koulutuksen tulee kattaa kestävän kehityksen niin teknis-taloudelliset, sosio-kulttuuriset kuin ekologisetkin ulottuvuudet. Tavoitteena on kestävän kehityksen kokonaisvaltaisen näkemyksen hahmottamiseen tähtäävä koulutus.

"Ympäristöalan yleisosaajan toimintaa voisi kuvata vertauksella yleislääkäriin, joka osaa ohjata potilaan oikealle erikoislääkärille jatkotutkimuksiin, jos oma tietotaito ei riitä. Yleislääkärin täytyy kuitenkin tietää mille erikoislääkärille potilaansa lähettää."

Generalistien kouluttaminen omana oppialanaan on mahdollisuus, joka tuottaa omanlaisensa haasteet ja mahdollisuudet. Kestävä kehitys ammattikorkeakoulutuksen ytimenä tuo vastuun kestävän kehityksen mukaisesta koulutuksen sisällöstä, opetuksesta ja menetelmistä koordinoidusti yhdelle koulutusohjelmalle tai suuntautumisvaihtoehdolle.

Generalisteja voidaan kouluttaa myös läpäisyperiaatteella. Tässä on usein heikkoutena se, että kenelläkään ei ole kokonaisvastuuta oppimistuloksista eikä myöskään näkemystä siitä, miten kestävän kehityksen ulottuvuus nivoutuu osaksi opiskelijan opetussuunnitelmaa.

2 Spesialisteja tarvitaan

Tarvitaan toki myös ammattilaisia, joilla voi olla hyvinkin kapea alan asiantuntemusta esimerkiksi jostakin luonnontieteellisestä ilmiöstä. On kuitenkin eri asia olla kestävän kehityksen perustiedot hankkinut spesialisti kuin spesialisti, jolla on vain hyvin vahva oman erityisalansa asiantuntijuus, esimerkiksi ekologinen perustieto luonnosta. Näin spesialistillakin tulisi olla tietoja ja taitoja kestävän kehityksen kaikista ulottuvuuksista ja sen lisäksi syvällistä asiantuntemusta joltakin erityisalalta. Spesialismia kuva parhaiten erikoistuminen tiettyyn alaan ja sen sisällä syvällisen ymmärryksen tavoittelu jostakin ongelmasta tai ilmiöstä. Spesialistin koulutuksessa korostuu tieteellisten lähtökohtien ja tutkimusmenetelmien oppiminen, ja muun muassa kenttäkursseja ja muita harjoitusjaksoja tulee olla paljon (kumisaapas ja pipettiosasto).

Kestävän kehityksen näkökulman integroiminen opetussuunnitelmaan opintojen alkuvaiheessa on tärkeää, jotta opiskelija voi suodattaa myöhemmin opetettavat erikoisalojen oppisisällöt myös kestävän kehityksen näkökulman kautta.

"Opiskelijoille tulisi saada heti aluksi ns. fleksiibeli aivovaurio ja kyky ottaa uutta tietoa vastaan. Tämä tarkoittaa ympäristötieteen mukaisen näkökulman omaksumista kaikkien opintojen lähtökohdaksi. Opiskelijat tulee pilata ensin ympäristötieteilijöiksi ja sitten vasta esimerkiksi kemisteiksi, eikä päinvastoin.”

\section{Uutta luova keke-osaaja}

Tutkimuksen mukaan tulevaisuuden ammattilaisten keskeisiä osaamisen peruskiviä ovat globalisaatiohaasteiden ymmärtäminen, kansainvälisten mahdollisuuksien ja haasteiden ymmärtäminen sekä työelämän joustavuuden, oikeudenmukaisuuden, vastuun ja velvollisuuksien ajallinen ja paikallinen ymmärtäminen. Globalisaation haaste työelämälle korostaa koulutuksessa sosiaalisen ja kulttuurisen kestävyyden merkitystä entistä enemmän - esimerkiksi elämänkatsomuksen muodossa. Tavoitteena on yhteiskunnallisten ja globaalien ulottuvuuksien ja yhteyksien kokonaisvaltainen ymmärtäminen.

Esimerkiksi viestinnän ammattilaisen voi tulevaisuudessa erottaa kestävän kehityksen perusteella: joko kestävä kehitys on sisäistetty arkirutiini itse ammattilaisella tai se on viestinnän kohde muttei arkirutiini tai se ei ole viestinnän kohteena eikä arkirutiinina tai sitten se on sekä viestinnän kohde että arkirutiini. Siis yksinkertaistaen kirjoittaako viestinnän ammattilainen kestävästä kehityksestä työkseen ja toimii itsekin kestävästi (sammuttaa esimerkiksi tietokoneensa)? Koulutuksen keinoin voi vaikuttaa molempiin. "Ajattelisin asiaa siten, että miten saataisiin ympäristöasioita ympättyä kaikkeen koulutukseen. Ihmisille pitäisi sisään rakentaa käsitys siitä, miten ympäristöasiat vaikuttavat omaankin alaan. Siten, että kaikilla 
päätöksentekijöillä olisi perustiedot ympäristöstä. Silloin ei välttämättä tarvitsisi kutsua niin paljon ulkopuolisia ympäristöasiantuntijoita, vaan jokaisessa asuisi pieni ympäristöasiantuntija.”

Uutta luovan ammattilaisen koulutus perustuu ennen kaikkea kriittiseen tarkasteluun, kokonaisvaltaiseen ilmiöiden ja ongelmien hahmottamiseen yhtäaikaisesti kaikista kestävän kehityksen ulottuvuuksista. Uutta luova ammattilainen osaa yhdistää esimerkiksi konsulttina kestävän kehityksen ulottuvuudet, kokemusperäisen ja eksplisiittisen tiedon ja markkinoinnin toisiinsa. Lopputuloksena voisi olla osaamista, jossa esimerkiksi kehitysyhteistyöhankkeessa paikallista osaamista hyödyntäen rakennetaan vastuullista pk-toimintaa naisten työllisyyden edistämiseksi. Samaan aikaan samainen konsultti soveltaa suomalaisen osaamisen niin vesihuollosta, jätevesistä, aurinkoenergiasta kuin sosiaaliturvasta ja pk-yritystoiminnan edellytyksistä saman hankkeen aikana - eikä erillisinä, toisistaan irrallaan olevina hankkeina. Tavoitteena on, että ongelmalähtöisessä, erilaiset näkökulmat, tavoitteet ja perinteet yhdistävässä avoimessa vuorovaikutuksessa syntyy uutta ymmärrystä, joka on myös laadukasta, vastuullista, taloudellista ja kestävää.

"Luovat ajatukset kehittyvät usein eri osaamisten rajapinnoilla. Ainakin tutkimuksessa tieteidenvälisyys on luovuuden lähde. Huippututkijat ovat usein tieteen marginaalissa, laidoilla."

\section{Päätelmiä}

Tapa toimia ja ajatella kestävästi edellyttää perustietoja ja taitoja, joihin kunkin ihmisen tulisi saada eväät jo päiväkodista ja koulusta: kestävästä kehityksestä pitäisi tulla yhtä arkinen tapa kuin käsienpesu.

Koulutuksessa puolestaan on syytä pohtia, miten kestävästä kehityksestä parhaiten opetaan. Jos kestävä kehitys on oma oppiaineensa, niin uhkana on kestävän kehityksen läpäisy, niin että se jää hipaisuksi. Vastuu kestävän kehityksen järjestämisestä täytyy olla selkeä - samalla se on myös kiinnitys näkökulmaan ja mahdollisesti toimintatapoihin ja menetelmiin.

Työelämässä kestävän kehityksen osaajan haaste on osaamisensa markkinointi: palkkaako yritys kestävään kehitykseen erikoistuneen sähköinsinöörin vai "tavallisen”? Luultavasti "tavallisen” ja perusteluina ei välttämättä ole mitkään eksplisiittisesti mitattavat syyt, kuten raha. Syy saattaa olla palkkaajan asenteessa: kestävä kehitys koetaan uhkana. Kestävä kehitys on syytä pukea erilaisiksi osaamissanoiksi, kuten energiatehokkuudeksi tai vastuulliseksi liiketoimintannaksi.

Tulevaisuuden ammatillisissa osaamistarpeissa kestävän kehityksen näkökulmasta painottuvat seuraavat seikat (vrt. Willamo, 2005, Kohl, 2007)

- kestävä kehitys tulee integroida läpäisevästi kaikkeen oppimiseen ja inhimilliseen toimintaan ylipäätään.

- Erilaisia kytkentöjä ja linkkejä tulee etsiä kestävän kehityksen ulkopuolelta: rajapintakeskusteluja, joissa uudet avaukset ja innovaatiot syntyvät. Koulutuksessa pitää pystyä tarjoamaan mahdollisuuksia näiden eri kytkentöjen ja raja-aitojen ylitykseen.

- Generalistien kouluttaminen ja asiantuntemus eivät poista tai ole uhka spesialistien kouluttamiselle.

- Poikkitieteellinen ja poikkihallinnollinen näkökulma on ennakointia - kokonaisvaltainen ajattelu on tullut jäädäkseen.

- Sosiaali- ja terveyspuolen ammattilaiset tarvitsevat kestävän kehityksen osaamista Eksplisiittisen tiedon rinnalle tulisi lisätä arvojen, tunteiden ja kokemusten näkökulmaa ja näiden pohtimista.

- Taide voi olla uusi avain kestävän kehityksen osaamisalojen linkittämiseen!

Kestävän kehityksen opettaminen ja sen tuleminen toiminnan ja ajattelun perustaksi vaatii asioiden uudelleen ajattelua. Tätä ajattelua leimaa ongelma- tai ilmiökohtainen kokonaisvaltainen, poikkisektorinen, poikkitieteellinen tarkastelu, jossa toki on mahdollista tarkastella spesialistin tai jopa atomistin silmin (vrt. Willamo, 2005). On myös siirrytty korjauksesta ennakointiin.

Tulevaisuuden kestävän kehityksen osaajat tunnistavat toiminnassaan ja ajattelussaan kokonaisvaltaisen, horisontaalisen ja vertikaalisen kestävän kehityksen piirteet. Paikallista tietämystä, tuntemuksia ja kokemuksia ei kummastella tai peitetä erilaisten kvantitatiivisten mittareiden alle. Näkemykset, kokemukset ja tuntemukset ovat vakavasti otettavia tietolähteitä ja osa kestävän kehityksen mukaista toimintaa ja ajattelua. Esimerkiksi eheän yhdyskunnan tulevaisuussuunnitelija osaa arvioida ja tulkita ihmisten pelkoja. 


\section{Kirjallisuus}

Antola Crowe, H. \& Kohl, J. (2007): Socially and Culturally Sustainable Education in Universities. In Book: Kaivola, T. \& Rohweder, L. (eds.) (2007): Towards Sustainable Development in Higher Education Reflections Ministry of 2007:6. http://www.minedu.fi/OPM/Julkaisut/2006/korkeakouluopetus_kestavaksi_opas_ykn_kestavaa_kehitysta_edist?lang $=\mathrm{fi}$

Coleman, D.A. (1993): Ecopolitics. Building a green society. Rutgers University Press. Brunswick. New Yearsey.

Heinonen, S. O. Hietanen, K. Kiiskilä \& L. Koskinen (2003). Kestääkö tietoyhteiskunta? Käsiteanalyysiä ja alustavia arvioita. Suomen ympäristö. Ympäristöpolitiikka 603. Helsinki: Ympäristöministeriö.

Hietanen, Olli; Kaivo-oja, Jari; Lauttamäki, Ville \& Nurmi, Timo (2005): Kansallinen tietoyhteiskuntastrategia. Tulevaisuusverstaat. Tulevaisuuden tutkimuskeskus, Turun kauppakorkeakoulu.www.tietoyhteiskuntaohjelma.fi/.../_files/75236818681266659/default/tulevaisuusverstasvälirap ortti1.pdf

Kohl, J., Salonen, S. ja Tapio, P. (2007): Kestävän kehityksen torille 2020: Kohtaamisia torilla.Loppuraportti. Tulevaisuuden tutkimuskeskuksen julkaisuja 2/2007. www.tukkk.fi/tutu

Kuosa, T., Kohl, J., Salonen, S. \& Tapio, P. 2006. Kestävän kehityksen torille 2020: Esiselvitys ympäristöalan koulutustarpeesta. Suomen Ympäristö 822. Helsinki: Ympäristöministeriö. 128 s.

Kyttä, M. \& Kahila, M. (2006): PehmoGIS. Elinympäristön koetun laadun kartoittajana. TKK. YTK:n julkaisuja. B 90.

Tapio, P. ,Kohl, J., Tikkanen, S. ja Salonen, S. 2007. Kestävän kehityksen torille 2020. Skenaarioraportti. Tulevaisuuden tutkimuskeskus. E-julkaisuja 1/2007. https://www.tukkk.fi/tutu/julkaisusarja_e.asp

Willamo, R. 1992:Pirstaleisen ihmisen pirstaleinen ympäristökoulutus. Teoksessa Kinttula, O. \& Parviainen, T. (toim.) Ojasta allikkoon? Puheenvuoroja ympäristökoulutuksen "itsestäänselvyyksistä". SYL:n julkaisu 3/92. Jyväskylän mlk.:Limes.

Willamo, R. 2005. Kokonaisvaltainen lähestymistapa ympäristönsuojelutieteessä. Sisällön moniulotteisuus ympäristönsuojelijan haasteena. Environmentalica Fennica 23. Väitöskirja. Helsinki: Helsingin yliopisto. 